$A D D I N$, Volume 11, Number 1, February 2017

\title{
INDONESIAN ISLAMIC CIVILIZATION IN INTERNET ERA: A Multiperspective Review
}

\section{Gondo Utomo}

Sebelas Maret University, Surakarta, Central Java, Indonesia gondo_u@kemenag.go.id

\begin{abstract}
Islam is not merely a religion, but it also as a civilization. Islam contains complete principles all all aspects of life, so that it became value order guiding buman life. But in its development, including in Indonesia, the implementation of Islam civilization value order starts to eroded by amount of things, one of them is due to internet development. Moslem people can easily adopt West behavior which unsuitably aligned with Islamic principles. This article tries to provide description about negative influence of internet on Islamic civilization in Indonesia, and also to provide offers through some perspective for the internet being used to strengthen Islamic civilization. If it stood on true use to share Islam principles, then intenet will have positive impacts for Islamic civilization in Indonesia.
\end{abstract}

Keywords: Islamic Civilization, Indonesia, Internet. 
Abstrak

Islam bukan hanya agama, tapi juga sebagai peradaban. Islam mengandung prinsip lengkap semua aspek kehidupan, sehingga menjadi nilai yang menuntun kebidupan manusia. Namun dalam perkembangannya, termasuk di Indonesia, penerapan tatanan nilai peradaban Islam mulai terkikis oleh sejumlah faktor, salah satunya karena perkembangan internet. Orang-orang Islam dapat dengan mudah mengadopsi perilaku Barat yang tidak sesuai dengan prinsipprinsip Islam. Artikel ini mencoba memberikan gambaran tentang pengaruh negatif internet terbadap peradaban Islam di Indonesia, dan juga untuk memberikan penawaran melalui beberapa perspektif untuk internet yang digunakan untuk. memperkuat peradaban Islam. Jika berpatokan pada prinsip-prinsip Islam, intenet akan berdampak. positif bagi peradaban Islam di Indonesia.

Kata Kunci: Peradaban Islam, Indonesia, Internet.

\section{A. Introduction}

World historian had noted that medieval era was an extraordinary dark period in relation with human existence. This idea was actually a clergy thought: an emerging thought from west civilization and centralized on merely west civilization history. It was indeed, medieval era was the dark century for Europe, but it was not meant that the darkness fall down in worldwide. In fact, on that time, it was Islamic civilization was in the peak of glory.

George Sarton mentioned an amount of matchless great moslem scientists on that periode, like Jabir Ibnu Hayyan, al-Kindi, al-Khawarizmi, al-Farghani, ar-Razi, Tsabit Ibn Qurrah, al-Battani, al-Farabi, Ibrahim Ibn Sinan, al-Mas'udi, at-Tabari, Abu al-Wafa, Ali Ibn Abbas, Abu alQasim, Ibn al-Jazzar, al-Biruni, Ibn Sina, Ibn Yunus, al-Kashi, 
Ibn al-Haitsam, Ali Ibn Isa al-Ghazali, Umar Kayam. ${ }^{1}$ Even Pervey Hoodbhoy argued that, "If one said to you that in Medieval was purely sterilized from scientific activities, then quote the abovementioned names. Know that they are alive and worked in a very short period from 750 to $1100 \mathrm{M} .{ }^{\prime 2}$

The bright traces of Islamic civilization was also found in Indonesia. Islamic civilization in the archipelago could not separated from the entrance history and the development of Islam in varied regions which are stated in varied theories. It had been started from thousands years, since the religion taught by Prophet Muhammad saw. entered and introduced in some of Indonesian territories.

In the entering and development process of Islam in archipelago, there was interaction between Islam and local civilizations. Civilization is the results of human thought and creativity. Koentjaraningrat stated that civilization is the entire systems, ideas, actions and results of human creation in humanly living as human property derived through learning process. ${ }^{3}$ Furthermore, civilization formed a behavior pattern sent through social, arts, religion, institution and all sectors of life which are the results of thoughts by some people.

By Muslims' creativity, the religion brought by Prophet Muhammad can develop, add more color and to eb the breath of varied local civilizations in many territories of the archipelago. The civilization was then conceived as all forms of civilizations which became holistic part and could not be separated from human life, both in physically or non physically.

${ }^{1}$ Budi Yuwono, Ilmuwan Islam Pelopor Sains Modern (Jakarta: Pustaka Qalam, 2005), p. 13.

${ }^{2}$ Pervey Hoodbhoy, Islam dan Sains (Bandung: Penerbit Pustaka, 2007), p. 110.

${ }^{3}$ Kholid Mawardi, “Seni Sebagai Ekspresi Profetik”, Jurnal Ibda', Vol. 11, No. 2, Juli-Desember 2013, p. 133. 
That civilization or civilization, inherently in Islamic principles system, is the taught of civilization and civilization in which teach human to be civilized and civilizationd according to Allah's will who teach human about goodness values. In other words, Islam civilization is the value order from where the basics located by Allah, embodied by Rasulullah, and preserved by the people. ${ }^{4}$

In field standpoints, Islamic values enters, inspires or even draws the local way of living and civilization to be a more enriched new or renewed civilization. Islamic values is also filter the civilization for the accordance with religion principles so that it made Islam civilization in Indonesia increasingly developed. It was, for example, by the emerged and glorious of Islam kingdoms, the born of many monumental classic yellow books from Islam prominent figures in archipelago, or when the growth and development of religion educational and Islamic religious institutions like Madrasah and Boarding Schools as the model of first community-based education institutions in archipelago.

Or in more simple form, Islam civilization was marked from the way Moslem dressing, to be translated in interhuman relational order, or in the Islamic management of family living. Islamic entire living system which based on Allah and His Rasul taughts are the inseparable part of Islamic civilization.

As a religion, Islam covers the natures of empirical (almadaniyyah) and also as a civilization (al-ḥadarah). ${ }^{5}$

Islam historically had served its own civilization in form of varied performance in law (al-qäün), politic, urbanity (al-imarah), economy, social living, phylosophy, technologi

${ }^{4}$ Abdurrahim Yapono, "Strategi Penanaman Nilai Peradaban Islam dalam Merespon Globalisasi”, Tsaqafah: Jurnal Peradaban Islam, Vol. 11, No. 1, Mei 2015, p. $72-73$.

${ }^{5}$ Qosim Nursheha Dzulhadi, “Islam Sebagai Agama dan Peradaban”, Tsaqafab: Jurnal Peradaban Islam, Vol. 11, No. 1, Mei 2015, p. 160. 
and agricivilization. Then, Islam civilization can be inferred as one spiritual-material (rübiyyah-máddiyyah), idealisticrealistic (misaliyyah-wäaíiyyah), divinity-humanity (rabbaniyyahinsaniyyah), morality-urbanity (akbTaqiyyah-'umraniyyah), and individual-social (fardiyyah-ijtima ${ }^{\prime}$ iyyah). This is the balance and mid civilization (at-tawazun wa al-wasatiyyah), which built upon one mid race as characterized by Allah: "... and Such that We had made you as the mid race."

It has become the basic characteristic that Islam has become the part of all human living aspects. It is as to be affirmed by Allah swt. in Qur'an means:

"You are the best nation produced [as an example] for mankind. You enjoin what is right and forbid what is wrong and believe in Allah. If only the People of the Scripture had believed, it would have been better for them. Among them are believers, but most of them are defiantly disobedient." (Q.S. Ali Imran [3]: 110)

In varied regions in Indonesia, there will be observed historical sites of Islamic civilization traces by which shows that Islam enters all living aspect of human being, so that then there came out an opinion the religion had become the primary element in a civilization. ${ }^{7}$ But in the development, there is tendencies of shifts in Islamic civilization. Such as by the eroded historical sites showed the glorious of Islamic civilization in Indonesia, or the emerging tendency to use West scientific mindset as the primary orientation in scientific improvement in Indonesia. Islam is as if "castrated" from varied sides. Such condition, among the others, is influenced by the technology and information improvement triggers for globalization.

${ }^{6}$ Ibid., p. 160.

${ }^{7}$ Adian Husaini, doctor from International Institute of Islamic Thought and Civilization International Islamic University Malaysia (ISTAC-IIUM), in Republika online at http://www.republika.co.id/, accessed at November 8, 2016. 
Globalization marked by the emerging information technology brought by Western countries was easily and fastly influence Indonesian people. Massive information technology in its roles in disseminating Western paradigm then made Islam civilization which previously put come colors of Islam principles, it slowly left behind by Islam community themselves. Presently, without the use of information technology, it is as if Indonesian people, specifically Moslems, are not being the part of modern people so that triggers the emerging excessive information technology use.

Then the question is, in the middle of high dissemination of varied propaganda of Western mindset and way of living which contracdictive with Islamic values, can Islamic civilization of Indonesia goes back to its glorious moments or minimally put some colors in Moslems life in archipelago? Is there a chance for Moslems to maintain Islam civilization track in Indonesia by using information technologi improvement brought by Western countries? In some perspective, it is very interesting to be analyzed.

\section{B. Discussion}

\section{Islamic Civilization in Indonesia}

Islam is a religion in which the principles cover all human life aspects. Not only in praying matters, or its relationship with the Creator, Islam is also regulate the relationship with fellow creatures of God. Al-Qur'an as the source of life guidance had covered all life aspects which then further affirmed in operational framework in form of saying, deed and commandment of Prophet Muhammad saw. in what so called as-Sunnah. Therefore, al-Qur'an and as-Sunnah are the sources of Islamic principle which must 
be dynamically conceived and can made to be the guidance throughout the ages in all respects. ${ }^{8}$

Islam is plurally acknowledged both as a religion and also civilization, ${ }^{9}$ because Islam is not only a religion, but it is a creator and living spirit for a world great civilization which the history widely spreaded more than 14 centuries. As a religion, Islam obliged people with aqidah concept which become the principle in daily life. Then, Islam also provides guidance for human for mu'amalah in wider context so that there born civilization construction in human life. ${ }^{10}$

Islamic civilization in Indonesia can not be separated from the history of Islam entrance in archipelago. Some of theories pointed out differently about the history of Islam entrance in Indonesia. One of the theory stated that the dissemination was in $13^{\text {th }}$ century, departed from Gujarat, and the actors were Indian merchants who had converted to Islam. ${ }^{11}$ Then there was also a theory stated the dissemination time was in $7^{\text {th }}$ century, with differed teaching origination in two notion, which are from Gujarat and Middle East (Egypt/Makkah), and the actor was Moslem merchants from Arab. And the last theory stated that Islam was from Persia in about $13^{\text {th }}$ century. One of the initiator of Persian theory was PA. Hoesin Djajadiningrat, who stated that Islam in Indonesia came from Persia, transit at Gujarat and introduced to archipelago. ${ }^{12}$

\footnotetext{
${ }^{8}$ Ajid Thohir, Perkembangan Peradaban di Kawasan Dunia Islam (Jakarta: RajaGrafindo Persada, 2004), p. 6.

${ }^{9}$ Seyyed Hossein Nasr and Huston Smith, Islam: Religion, History, and Civilization (Lahore-Pakistan: Suhail Academy, 2005), p. xi.

${ }^{10}$ Thohir, Perkembangan Peradaban, p. 7.

${ }^{11}$ Dwi Hartini, Masuknya Pengaruh Islam di Indonesia (Jakarta: Pustaka Setia, 2000), p. 4.

${ }^{12}$ Muhammad Syarif Hidayatullah. "Teori-teori Masuknya Islam ke Wilayah Timur Indonesia", Jurnal Ilmiah Non Seminar, Fakultas Ilmu Pengetahuan Budaya Universitas Indonesia, 2013, p. 9.
} 
According to Hamka, Islam in Indonesia is came from Makkah in $7^{\text {th }}$ century or the first century of Hijriyah. ${ }^{13}$ This notion is laid that actually in $13^{\text {th }}$ century in Indonesia had founded Islamic politics so that Hamka stated that Islam had entered in Indonesia far before $13^{\text {th }}$ century. If related with the explanation from a study of ancient Arabian literature, there mentioned $\mathrm{Al}$ Hind as India or Chinese islands, so that it was most likely that Arabian had came to Indonesia since $2^{\text {nd }}$ century. But eventually, some of Islam prominent figures in Indoensia agreed that Islam in archipelago came from Arab and introduced in $7^{\text {th }}$ century by then fastly grown such can be observed in $13^{\text {th }}$ century. ${ }^{14}$

The Indonesian long history had noted that Islam had colored this nation life. Started from sultanate era and Islam kingdoms in independent struggle period, Orde Lama, Orde Baru, and present reformation period. As a religion majority held by most residents, Islam civilization in Indonesia shaped in varied forms of social, state and national life.

Nonetheless, the fact faced presently is the confrontation in Moslem internal who want to take back the glorious moments of Islam civilization through the movement to ground back or internalize Islam religion on Moslem themselves. In other hand, the renewal spirit then constrained by the cultural expansion and Western civilization brought in globalization context through information technologi improvement.

If science is considered as a milestone of a civilization, then Islam education is one of the primary problem faced by Islamic civilization in Indonesia presently. Islam education is faced on the fact of globalization as an external factor, ${ }^{15}$

${ }^{13}$ Ibid., p. 8 .

${ }^{14} \mathrm{Ibid}$., p. 9.

${ }^{15}$ M. Ihsan Dacholfany, "Reformasi Pendidikan Islam dalam Menghadapi Era Globalisasi: Sebuah Tantangan dan Harapan", Akademika, Vol. 20, No. 1, Januari-Juni 2015, p. 191. 
and the challenges of Islamic internal education itself. It's been a long period for Islamic thinker figures in Indonesia are restless by the worse imbalance between the amount of Islam majority and their life quality. Of the imbalance, the position of the majority is in low quality, became the burden of Islam as religion which requires to develop good, qualified civilization on the earth. ${ }^{16}$

The lag of Islamic education which is so that influencing on the community, termed by Ahmad Syafii Maarif as quality impaired is not only resulted from the high of Islam education institution with low management quality. About the curriculum, means and infrastructure equipment, conscious delay to manage Islam education, orientation on Islam education management and also varied reality constrained on educational development is also faced by Islamic education field in Indonesia. In fact, by recent technology improvement, it can provide a chance for Islam education in Indonesia to implement varied innovation so it can developed, qualified and become a reference for other educational sector. ${ }^{17}$

It can be factually observed that Islam religion is a religion closely related with science. Al-Qur'an verses can take people to meet with varied science theories presently developed. ${ }^{18}$ Evenmore, Islam obliged people to read, to think and to act other things related with education and science. The Prophet saw. in some hadits showed the obligation to learn science for Moslem, which must be pursued in lifetime, although the knowledge is in other part of the world.

\footnotetext{
${ }^{16}$ Ahmad Syafii Maarif, Islam dalam Bingkai Keindonesiaan dan Kemanusiaan: Sebuah Refleksi Sejarah (Bandung: Mizan, 2015), p. 224.

${ }^{17}$ Yuberti. "Peran Teknologi Pendidikan Islam pada Era Global", Akademika, Vol. 20, No. 1, Januari-Juni 2015, p. 138.

${ }^{18}$ Q.S. Ali Imran [3]: 190-191.
} 
Al-Qur'an taught to Moslem to put the understanding on a verse based on two things: think and irikr. In sit, stand, lay down or in any kind of situation, they shall keep try to understand kauniyah verses in universe, until they obtain integrated conclusion that kauniyah verses are the evidence of "truth" such taught by qauliyah verses. ${ }^{19}$

Such matters strengthen the fact that education is the part to be accounted deeply by Moslem in Indonesia for Islam civilization had no tendencies to stagnant or even decrement. Islam education shall be able to play the roles in improving science quality so that it can reassure the believer that Islam teaching is a principles to be implemented and even required to guide their life along all periods. Education and science is very important to avoid a perception in modern era that religion is not required for modern people because it conversely stood with the improvement. ${ }^{20}$

Without good and appropriate education, Moslem will not use al-Qur'an in fully meaning as the complete source of guidance for their life. If it continually occured, Moslem can no longer became a model, and Islam civilization will be eroded. The opinion and policies which separating religion and science must be removed from Moslem live in Indonesia. Improving Islamic education quality is an obligation to be conducted. But in other hand, it is constrained because there is still education dichotomy based on Western orientation and religion education.

From formal side of Islamic education improvement effort, it is challenged, then the intellectuals and Islam prominent figures in Indonesia must put some more effort for Islam education in informal side, like to use internet

\footnotetext{
${ }^{19}$ Agus Mustofa, Membonsai Islam (Surabaya: Padma Press, 2006), p. 233.

${ }^{20}$ Kamaruzzaman, Relasi Islam dan Negara: Perspektif Modernis dan Fundamentalis (Magelang: Penerbit Yayasan Indonesiatera, 2001), p. 123.
} 
which presently widely used from which covered in varied social living sectors. The use of internet in globalization era is a obligatory implementation to be applied in daily life of an individual, and became a necessity to push quality improvement of Islam education to maintain Islam civilization in Indonesia.

\section{Globalization and Internet}

Globalization had brought its imfluence for all social living in Indonesia, including in religion sector. Globalization even had changed human daily life, and simultaneously, globalization created a new transnational system and power. ${ }^{21}$ It can be observed in the influence of globalization in Indonesia, like the dependencies of people to use goods and services imported from other countries, or in lower level, trends in fashion or behavior with more character on more consumptive, hedonism and dependencies on west civilizations.

Globalization era had made the world became one or in Thomas Friedman words-a columnist in New York Timescalled the world is flat. Globalization flow had made all parts of the world are connected so that according to Anthony Giddens, dinstinction had became avoidable in entire part of the world. Each nation had prepared to accept or refuse civilizations and values which are inaccordance with their own civilizations. ${ }^{22}$

Globalization and information technology are two unseparated things. The unification of many part of the world to be one "sheet" is occurred due to information

${ }^{21}$ Syamsul Aripin, "Strategi Pendidikan Islam dalam Upaya Menjawab Tantangan Globalisasi", Tarbiya: Journal of Education in Muslim Society, Vol. 1, No. 2, Desember 2014, p. 165.

${ }^{22} \mathrm{John}$ Perkins, Confessions of an Economic Hit Man (T.K.: Berrett-Koehler Publishers, 2004), p. 15. 
technology which allowed all part of the world to be interconnected. Globalization is identified by the communication, information and transportation technology improvement so that it produces transformation in human civilization and civilization. Globalization is also related with term modernization and modernism which connected with the change of mindset, science and technology improvement and also cultural transition from the old to the new one.

Marshal McLuhan argued that information technology, which one of them formed as internet, had caused the world to be "global vilage" where internet had made possible for people to access varied kinds of civilization from other parts of the world, anytime and anywhere. ${ }^{23}$ McLuhan noted that community who live in varied part of the world started to immitate some values, mindset and beliefs from other community in other part of the world. ${ }^{24}$

In Indonesia, internet had played an important role since Orde Baru regime started to implement internet infrastructure development in about mid 1990s. Since then, internet widely spreaded in varied life sector, including economy, government until public sector. In the development, internet then became a new media to transport and express freedom. The amount of internet user in Indonesia presently had amounted of about 130 million people.

The improvement of information technology through internet use in several recent years had push the establishment of new media. Term new media is used to represent the existence of social media epidemically spread in community,

${ }^{23}$ Gati Gayatri, "Pendekatan New Media dalam Strategi Public Relation", Paper, presented in Seminar Nasional Program Pascasarjana Ilmu Komunikasi Univesitas Sebelas Maret, Surakarta, November 7, 2016, p. 5.

${ }^{24}$ Abdurrahim Yapono, "Strategi Penanaman Nilai Peradaban Islam dalam Merespon Globalisasi", Tsaqafah: Jurnal Peradaban Islam, Vol. 11, No. 1, Mei 2015, p. 72-73. 
like Facebook, Twitter, Path, Instagram, Line, and varied other social networks. The existence of new media is slowly shift the existing conventional media, the term for old media like newspaper, magazine, television, or radio.

New media is then became one of necessity in social life, including in Indonesia. It can be easily observed in all ages level who interestedly drawn into their smartphones to access varied information through the new media. And unfortunately, the disseminated information frequently those which are inappropriate with Islam values, so that the existence of new media became a distinct threat for the effort of Islam principles internalization conducted to strengthen Islam civilization in Indonesia.

It such like facebook social network, will be easily access to find information about events or even religion principles which shall be confirmed on its truth by Facebook users. But in fact, it seldom conducted because most of Facebook users are directly convinced on such information disseminated in their social network, so that unconsciously, the erasure process of Islam civilization is unavoidably became ongoing event in Moslem community.

Even more frequently there publicated in mass media about fraudulent victims committed through Facebook and other social networks. Or about those who are trapped in heresy and got lost due to interaction through the new media. All of those provided examples of negative impact of intenet use as the derivative of information technology improvement and globalization era.

To name some of the many, through intenet, Moslem can access varied religious information or about the Islamic principles themselves. However, due to relied on information from the internet, it can be the religious principles are not in accordance with the pure Islamic principles or those taught 
through national educational syste. Many publication in some mass meddia in recent years showed the consequences of direct interaction with intenet by which then rise out wrong interpretation on Islamic principles, or in wider form, there will emerge thaught which prosecute Islam principle truth taught and followed by the community during these times.

When using the internet, one can also in accessing the internet content on Islam religion. But on the same time, one can also create internet content by disseminate information read by them. In this context, internet is the informationdisseminating media, and the internet contents are also at once as the information-disseminatiing media as well. The strength is high to determine what to be believed by the internet user about the good or the bad of something, including in its relation with Islam civilization in Indonesia.

Nevertheless, the existence of internet is actually able to be utilized in pushing internalization effort of Islam principles to Moslem who use the media. By the wide coverage and ease accessibility, the new media can be located to disseminate Islam principles and other diversed matters to preserve Islam civilizations.

If related with internet user in Indonesia who use social network to share information, the amount of user behavior is expected to reach 129,3 million. The amount had became a high potential for Moslem intellectual or Islam organization to implement any steps to preserve Islam civilization. Social network as new media has its own strength, weakness, opportunity and threats if to be used in structured, systematic and massive way in preserving Islam civilization in Indonesia and even to develop it to the end of the time.

It supported by the increasing Islamic spirit in Moslem in Indonesia, like the increasing amounts of majelis taklim, the developing Islamic fashion and syar'i, and the growth 
of syariah economy. Additionally, it also observed the more Islam organization established, the euphoria of Islamic recital, or the habit to say Islamic greet in daily life. ${ }^{25}$ For correct use purpose, it must be analyzed on strength, weakness, opportunity and threats faced on internet in terms of Islam civilization existence preservation in Indonesia.

\section{SWOT Analysis: Internet Use to Preserve Islam Civilization in Indonesia}

Islam is a religion and also as a civilization. Therefore, the decreasing religious life quality in Moslem is also a quality decrement in Indonesia. Religious life will be good if Moslem has sufficient knowledge on Islam principles as a teaching which providing all guidance on varied life requirements for Moslem in all aspects.

Therefore, to preserve Islam civilization in Indonesia can be strived by disseminating the Islamic knowledge and science to those to be conceived and implemented. The dissemination is one of the possible way to be conducted through internet network and varied media connected in the network.

\section{a. Strenght}

The massive use of internet by Indonesian community is derived from the results of survey by Asosiasi Penyelenggara Jasa Internet Indonesia (APJII) in 2016 showed that not less than 132,7 million Indonesian people are intenet user. ${ }^{26}$ This amount reached 51,8 percent of all population of Indonesian people which totally reached of 256,2 million. The intenet users are divided into 52,5 percent males and

${ }^{25}$ Riswinarno, "Peradaban Islam Modern di Asia Tenggara", in Siti Maryam (ed.), Sejarah Peradaban Islam dari Masa Klasik hingga Modern (Yogyakarta: LESFI, 2009), p. 349.

${ }^{26}$ Hafied Cangara, "Media Baru, Public Relations, dan Perencanaan Komunikasi”, Paper, presented in Seminar Nasional Program Pascasarjana Ilmu Komunikasi Univesitas Sebelas Maret, Surakarta, November 7, 2016, p. 3. 
47,5 percent females, where of 86,3 million internet users are in Java island, or reaching of 65 percent of all internet user in Indonesia.

Internet is able to unify hundreds million of users in one interconnected network. If an information is disseminated through internet, then it has potential to be read by at least 132,7 million internet users in Indonesia. Or if assumed that the internet users who are Moslem of 70 percent of the amounts, then we can imagine the disaster if the information disseminated is the information aimed to weaken Islam civilization in Indonesia.

One of internet primary strength is the ability to disseminate information in short period but in very wide coverage by which shall be utilized to disseminate Islam principles or in form of Islam wider education. Anything in internet are able to reach those in global coverage, can be accessed internationally and provide influences on public behavior. ${ }^{27}$

The internet strength is supported by the mobile characteristic so that it can be accessed anywhere and anytime. The mobile character facilitates the movement in media use so that it can minimalize the constraints with static and physic natures. Internet, which presently tend to use wireless and virtual technologies, is able to remove restrictions owned by other conventional information-disseminating medias.

If Islam principles is widely spreaded continually through intenet, then it will provide distinct strength to persuade the community to comprehend the principles. Internet had made possible for the user to participate in disseminate anything, including Islam principles so that it will then produce multiplier effect in form of information

${ }^{27}$ Philip Seib, New Media and the New Middle East (New York: Palgrave MacMillan, 2007), p. xiv. 
sharing in parallel and continual way. In turn, people who initially has not access Islam teaching will be pushed to access it or obtain certain understanding on Islamic teaching from others who previously had accessed in the internet.

The mobile nature had made possible for Moslem to access Islamic teaching anywhere anytime, as long as the internet coverage is available and the person has will and interest to access it. Religious speech material sharing can be conducted without the use of physical material or in form of face to face lecture with community of majelis taklim, but it can be conducted by more practically, internet network.

\section{b. Weakness}

Despite with its strength, internet also has weaknesses. One of them is one way communication character. Although at present improvement it made possible for two way communication through internet, but the absence of direct physical contact will provide distinct influence on two way communication effectiveness. The involvement of emotional and physical contact elements in communication means importantly for the message can be fully received by public who become the target of information sharing.

Islam missionaries are as the communicators who will convey the message to public, as the communicants. The message received by the public shall be the same with what actually conveyed by the Islam teachers regardless the communication channels being used. But if the communication is one way characterized or even two way but without direct contacts, bias in the understanding is possible for those who accept the Islam principles through the internet. 
The interpretation on message has several influencing factors. ${ }^{28}$ The factors are: (1) the person who interpret so that the interpretation on a message can be diversed among one and the others, and also involving meaning alteration by the interactant in communication, which can made the interpretation on one message can be differed on the same message but in different time; (2) context factor which related with the message so that the same message can be differently interpreted due to contextual difference on interpretation time; and also (3) rules factor in relation with the interpretation of message, where the arranged message is strictly ordered under the rules so that the interpretation is also involving the prevailing rules in a specific social situation. Results of a research showed that face to face intraction has greater influence if compared with virtual interaction on the understanding of information being shared by each participants involved in the research. ${ }^{29}$

Other weakness is the possibility to be attacked by hacker. Security system software in internet network frequently insufficient to prevent hacker to disrupt the internet contents, so that it is frequently occured the alteration of internet contents committed by the hacker. Such condition is certainly risky if conducted on contents containing Islamic principles and will incur distinct problems.

\section{c. Opportunity}

Science and technology improvement had made possible for internet working system to be more facilitative on the acceptance of Islamic principles sharing to public.

${ }^{28}$ Joseph DeVito, Human Communication: the Basic Course (New York: Pearson Education, Inc., 2003), p. 6.

${ }^{29}$ Andreas Mojzisch, Rudolf Kerschreiter, Nadira Faulmüller, Frank Vogelgesang, and Stefan Schulz-Hardt, "The Consistency Principle in Interpersonal Communication: Consequences of Preference Confirmation and Disconfirmation in Collective Decision Making", Journal of Personality and Social Psychology, Vol. 106, No. 6, 2014, p. 961-977. 
This knowlegge improvement is also made people closer with internet use so that it will provide more accessibility for Moslem on Islamic principle informational sources.

The establishment of the Acts No. 11/2008 on Electronic Information and Transaction is also provide more opportunity for internet use to educate national life, including for Moslem. The government through the acts provided protection and legal guarantee for public in their activities to use information technology.

\section{d. Threat}

Barriers faced in relation with internet use to share Islamic principles in efforts of re-affirm Islam civilization has not been evenly distributed, specifically on the infrastructure and suprastructures of intenet network in Indonesia. Consequently, intenet users are dominantly located in Java island as the territory with best accessibility. While in other islands, like Kalimantan, internet user only reaches of 7.685.982. The least internet users is in Maluku and Papua, which only reaches of 3.330.986. ${ }^{30}$

\section{Designing Communication Strategy to Strengthen Islam Civilization}

The shared persuasion, suggestion or principles of Islam are basically the part of the effort to communicate the importance of principles understanding and implementation. Effective dissemination of persuasion or information must be designed on the base of situation, time, location and target.

Allah swt. in Q.S. al-Hasyr [59]: 18 had Said, means that "O you who have believed, fear Allah. And let every soul look to what it has put forth for tomorrow and fear

${ }^{30}$ Paper by Hafied Cangara, Professor at Ilmu Komunikasi Universitas Hasanuddin Makassar, presented in Seminar Nasional Program Pascasarjana Ilmu Komunikasi Univesitas Sebelas Maret, Surakarta, November 7, 2016, p. 4. 
Allah. Indeed, Allah is acquainted with what you do." Then in other Surah, Allah swt. Said, means that, "And don't you follow what you're yourself not own any knowledge about. It is acually the hearing, vision and heart, all of those will be hold accountable." (Q.S. al-Isra' [17]: 16).

From the two verses, at least we can observed that Moslem must take some account on what they're doing in the relation with the implication accepted in the future. For them can consider what things to be done and things to be obtained, it included in consideration when they're arrange planning, where a plan will be consider the steps to be implemented, the objective to be reached, alternative methods to be applied in case of barriers found and other diversed consideration.

Then Allah swt. is also ask to Moslem not to do anything they're not understand on. The planning is basically the form of effort to know things to be done and things to be reached on the implementation. It means that Islam teaches to Moslem to arrange plan on varied aspects.

There are varied planning model for communication strategy. Any strategy in use, there must be confirmed on one which in accordance with primary objective, which is to re-affirm Islam civilization in Indonesia. It means we have to find the most precise communication strategic planning model for the appropriateness with Indonesian characteristics. If all planning stages had implemented consistently, then it will be possible for Islam civilization in Indonesia will be come into glorious moments, at least in level of Islamic values implementation by Moslem In Indonesia. 


\section{Conclusion}

Islam is a religion and also a civilization because it provides complete guidance for human life order. History had noted many of Islamic civilization glory in the past in varied parts of the world, including in Indonesia. However, along with times, the glory started to faded due to the principles are left behind by its own community. One of the cause is the flow of West civilization brought by information technology improvement in form of internet. Despite it made Moslem immitate West civilization which inappropriate with those taught in Islam, it is in fact can be used to reinforce Islam civilization in Indonesia. With all of its strength, weakness, opportunity and threats on the internet, combined with precise communication strategic planning, then it is not impossible for the internalization of Islam principles on the believers can be implemented in structured and massive way. Such condition will push the improvement of Islam teaching comprehension, the implementation of Islam principles in daily life and made Islam civilization in Indonesia finds back the glorious moment. 


\section{REFERENCES}

Al-Qur'an dan Terjemabnya. Jakarta: Darus Sunnah, 2016.

Aripin, S. "Strategi Pendidikan Islam dalam Upaya Menjawab Tantangan Globalisasi”, Tarbiya: Journal of Education in Muslim Society, Vol. 1, No. 2, Desember 2014.

Baran, S.J. Introduction to Mass Media Communication, Media Literacy, and Culture. New York: McGraw Hill, 2008.

Cangara, H. "Media Baru, Public Relations, dan Perencanaan Komunikasi", Paper, Presented at Program Pascasarjana Ilmu Komunikasi Universitas Sebelas Maret, Surakarta, Novemver 7, 2016.

Dacholfany, M.I. "Reformasi Pendidikan Islam dalam Menghadapi Era Globalisasi: Sebuah Tantangan dan Harapan", Akademika, Vol. 20, No. 1, Januari-Juni 2015.

DeVito, J. Human Communication: the Basic Course. New York: Pearson Education, Inc., 2003.

Dzulhadi, Q.N. "Islam Sebagai Agama dan Peradaban", Tsaqafab: Jurnal Peradaban Islam, Vol. 11, No. 1, Mei 2015.

Gayatri, G. "Pemanfaatan Media Baru dalam Komunikasi Kehumasan Pemerintah", Paper, Presented at Program Pascasarjana Ilmu Komunikasi Universitas Sebelas Maret, Surakarta, November 7, 2016.

Hartini, D. Masuknya Pengaruh Islam di Indonesia. Jakarta: Pustaka Setia, 2000.

Hidayatullah, M.S. "Teori-teori Masuknya Islam ke Wilayah Timur Indonesia", Jurnal Ilmiah Non Seminar. Fakultas Ilmu Pengetahuan Budaya Universitas Indonesia, 2013. 
Hill, D. and K. Sen. The Internet in Indonesia's New Democracy. Oxon: Routledge, 2005.

Hoodbhoy, P. Islam dan Sains. Bandung: Pustaka, 2007.

Kamaruzzaman. Relasi Islam dan Negara: Perspektif Modernis dan Fundamentalis. Magelang: Penerbit Yayasan Indonesiatera, 2001.

Lubis, M.R. "Melacak Akar Paham Teologi Islam di Indonesia", Jurnal Harmoni, Vol. 14, No. 2, MeiAgustus 2015.

Maarif, A.S. Islam dalam Bingkai Keindonesiaan dan Kemanusiaan: Sebuah Refleksi Sejarah. Bandung: Mizan, 2015.

Mawardi, K. "Seni Sebagai Ekspresi Profetik", Jurnal Ibda', Vol. 11, No. 2, Desember 2013.

Mojzisch, Andreas, Rudolf Kerschreiter, Nadira Faulmüller, Frank Vogelgesang, and Stefan Schulz-Hardt. "The Consistency Principle in Internal Communication: Consequences of Preferece Confirmation and Disconfirmation in Collective Decision Making”, Journal of Personality and Social Psychology, Vol. 106, No. 6, 2014.

Mustofa, A. Membonsai Islam. Surabaya: Padma Press, 2006.

Nasr, S.H. and H. Smith. Islam: Religion, History, and Civilization. Lahore-Pakistan: Suhail Academy, 2005.

"Perspektif Peradaban Islam Indonesia", Article, from Republika online at http://www.republica.co.id, accessed at April 18, 2016.

Perkins, J. Confessions of an Economic Hit Man. T.K.: BerretKoehler Publishers, 2004.

Riswinarno. "Peradaban Islam Modern di Asia Tenggara", in Siti Maryam (ed.). Sejarah Peradaban Islam dari Masa Klasik hingga Modern. Yogyakarta: LESFI, 2009. 
Seib, P. New Media and the New Middle East. New York: Palgrave MacMillan, 2007.

Thohir, A. Perkembangan Peradaban di Kawasan Dunia Islam. Jakarta: RajaGrafindo Persada, 2004.

Yapono, A. "Strategi Penanaman Nilai Peradaban Islam dalam Merespon Globalisasi”, Tsaqafab: Jurnal Peradaban Islam, Vol. 11, No. 1, Mei 2015.

Yuberti. "Peran Teknologi Pendidikan Islam pada Era Globalisasi", Akademika, Vol. 20, No. 1, JanuariJuni 2015.

Yuwono, B. Ilmunvan Islam Pelopor Sains Modern. Jakarta: Pustaka Qalam, 2005. 